Acta Universitatis Nicolai Copernici • Pedagogika XXXVI/2/2018

Nauki Humanistyczno-Społeczne • Zeszyt 446

DOI: http://dx.doi.org/10.12775/AUNC_PED.2018.016

\title{
Paulina Depczyńska
}

UJK w Kielcach

Filia w Piotrkowie Trybunalskim

ORCID: 0000-0002-5803-2035

\section{Partycypacja polityczna}

JAKO OŚ KSZTAETOWANIA SIĘ

SPOEECZEŃSTWA OBYWATELSKIEGO

I WZORCÓW OBYWATELSKOŚCI

Political Participation as an Axis

of Shaping Civil Society and Patterns of Citizenship

\section{Streszczenie:}

$\mathrm{W}$ artykule zostaje poddany analizie fenomen partycypacji politycznej jako osi konstrukcyjnej społeczeństwa obywatelskiego. Rozważania osadzone są w nurcie badań nad zmieniającym się paradygmatem społeczeństwa obywatelskiego i wzorcem „dobrego” obywatela. Na zakończenie opracowania zostają przytoczone wnioski z analizy, które w obliczu internacjonalizacji mogą okazać się przydatne w badaniach nad społeczeństwem i systemami edukacji obywatelskiej.

Słow a kluczowe: społeczeństwo obywatelskie, partycypacja polityczna, edukacja obywatelska. 


\section{AbSTRACT:}

The article presents the concept of political participation as theoretical construction, specifically taking into consideration its role in building democracy and identity. This paper also outlines the terminological problems in civic society. The main subject of discussion in the article is the evolving model of citizen and his political participation. The conclusions from this analysis may be useful in social studies or in the implementation of innovative system solutions in civic education.

Ke y w ord s : civic society, political participation, civic education.

\section{Ewoluowanie teoretycznej koncepcji społeczeństwa obywatelskiego}

Tdea obywatelstwa jest ideą sięgającą czasów starożytnych, opierająـcą się na zależności między państwem, obywatelem a określonym terytorium. Wprawdzie relacja ta zmienia się ze względu na określone uwarunkowania, obowiązujące $\mathrm{w}$ danym czasie systemy ideologiczne, normatywne, filozoficzne, to jednocześnie tworzy siatkę pojęć, w której zawiera się obywatelstwo. Wprawdzie nie można bezpośrednio porównywać obywatelstwa w starożytnej Grecji ze współczesnym modelem obywatelstwa, to jednak wspólne dla rozważań będą pojęcia definiujące i opisujące relacje w układzie sił między obywatelem, państwem a społeczeństwem.

Wraz z kształtowaniem się idei obywatelstwa powstaje i ewoluuje idea społeczeństwa obywatelskiego. Obecnie pojęcie społeczeństwa obywatelskiego na trwałe wrosło w opisywanie rzeczywistości, doczekało się szeregu interpretacji oraz definicji, a jednocześnie uległo rozwarstwieniu, ponieważ z jednej strony zdominowało język przedstawicieli nauk społecznych, politycznych, humanistycznych, ekonomicznych czy prawnych, z drugiej strony stało się częścią języka dziennikarzy, publicystów, polityków i obywateli, w wielu przypadkach często nadużywane lub używane w sposób nieadekwatny, niekonsekwentny, niejednolity. 
Wobec powyższego rodzi się kwestia zdefiniowania fenomenu społeczeństwa obywatelskiego, pytanie o cechy „tworzące” dobrego i dojrzałego obywatela oraz pytanie o wzajemne relacje zachodzące między społeczeństwem obywatelskim a partycypacją polityczną w środowisku demokratycznym.

W literaturze przedmiotu można odnaleźć bardzo szerokie spektrum definicyjne dla terminu „społeczeństwo obywatelskie”. Punkt wyjścia do rozważań stanowi pojęcie wyprowadzone od Arystotelesa koinonia politike, rozróżniające wspólnotę państwa-miasta oraz wspólnotę publiczną. Pojęcie to zostało przetłumaczone przez Cycerona na język łaciński jako societas civilis sive communitas ${ }^{1}$. Można zauważyć, że właściwie od czasów antycznych po nowożytność bardzo trudno jest wykazać rozłączność tych dwóch sfer, to jest sfery societas civilis i sfery państwa. U Tomasza Hobbesa body politic i civil society to niemalże te same zjawiska, które Grecy nazywali polis ${ }^{2}$, podobnie Immanuel Kant wiąże społeczeństwo i państwo w Metafizycznych podstawach nauki prawa ${ }^{3}$. Podział wyżej wymienionych pojęć można zaobserwować u Karola Monteskiusza w dziele $O$ duchu praw, w którym to wprowadza rozróżnienie na l'etat civil i l'etat politique ${ }^{4}$.

Wiek XVII i XVIII zmieniają pojmowanie społeczeństwa obywatelskiego z uwagi na rozwijający się kapitalizm, przy czym zauważa się tendencję do rozwijania kwestii ekonomicznych i praw własności, do dyskusji z systemem absolutyzmu oraz do konstruowania idei społeczeństwa obywatelskiego opartych nie tylko na rozbudowie katalogu praw jednostki, ale również w oderwaniu kategorii społeczeństwa obywatelskiego od sfery czysto politycznej. Ostatecznego podziału i wyodrębnienia istotowości państwa od istotowości społeczeństwa obywatelskiego dokonuje Georg Wilhelm Friedrich Hegel. Poszukuje on miejsca

1 Cyceron, O państwie. O prawach, przeł. I. Żółtowska, Kęty 1999, I, XXXII. 49, s. 55.

2 W. R. Schäfer, Politische Theorie heute. Neuere Tendenzen und Entwicklungen, Oldenbourg 2000, s. 76-77.

3 Por. I. Kant, Metafizyczne podstawy nauki prawa, Kęty 2006.

4 https://wolnelektury.pl/media/book/pdf/o-duchu-praw.pdf, s. 6-8 (dostęp: 01.06.2017). 
dla społeczeństwa obywatelskiego w przestrzeni, którą upatruje między jednostką a państwem i tłumaczy societas civilis jako społeczeństwo obywatelskie (bürgerliche Gesellschaft) ${ }^{5}$. Niemiecki filozof stoi na stanowisku, że rozwój społeczny możliwy jest tylko poprzez trzy nurty: rodzinę, społeczeństwo obywatelski i państwo ${ }^{6}$. Podobnie jak Georg Hegel pojęciem społeczeństwa obywatelskiego posługuje się Antonio Gramsci, podejmując debatę nad terminem społeczeństwa obywatelskiego w potrójnym ujęciu. Po pierwsze, upatruje w nim filar gospodarczy, filar państwowy oraz właśnie społeczeństwo obywatelskie, które rozwija się i realizuje w uwarunkowaniach społecznych, politycznych, gospodarczych i kulturowych. Dorota Pietrzyk-Reeves wskazuje jednak, iż niezwykle istotne $\mathrm{w}$ interpretacji pojęcia u Antonio Gramsciego jest wprowadzenie rozróżnienia między etyką i polityką; etyka jest domeną społeczeństwa obywatelskiego, którego domeną jest wolność, natomiast polityka wpisana jest w funkcjonowanie państwa. Dlatego Antonio Gramsci szczególną wagę przypisuje partiom politycznym mającym wpływ na kształtowanie się poglądów i postaw obywateli.

Dyskusja o społeczeństwie obywatelskim w wieku XIX nie zamiera. Alexis de Tocqueville jako jeden z pierwszych myślicieli wprowadza odrębność między społeczeństwem obywatelskim a państwem, to znaczy że przestrzeń aktywności obywateli jest sferą samą w sobie, ale tym samym również stanowi część sfery władzy. Wzajemne przenikanie się zależności przejawia się np. w udziale obywateli w sprawowaniu władzy poprzez uczestnictwo w wyborach ${ }^{8}$, istotny jest jednak fakt, że obie wspomniane sfery mogą istnieć obok siebie.

5 O. Brunner (Hg.), Geschichtlicher Grundbegriff. Historisches Lexikon zur politisch-sozialen Sprache in Deutschland, Band 3, Stuttgart 1975, s. 719-800.

6 G. W. F. Hegel, Zasady filozofii prawa, Warszawa 1969, § 238, s. 226-227, oraz § 181, s. 187-188.

7 D. Pietrzyk-Reeves, Idea społeczeństwa obywatelskiego: Współczesna debata i jej źródła, Toruń 2012.

8 Por. B. Poboży, Idea społeczeństwa obywatelskiego, „Społeczeństwo i Polityka”, 2005 nr 1(2), s. 13-20. Autor wskazuje, że analiza społeczeństwa obywatelskiego podjęta przez Alexisa de Toqueville odnosi się do społeczeństwa amerykańskiego, które charakteryzuje wysoki stopień instytucjonalizmu i aktywności przejawiającej się zakładaniu stowarzyszeń, ugrupowań, organizacji. 
Idea społeczeństwa obywatelskiego jest bardzo żywa w refleksji Karola Poppera, który w swoim dziele Społeczeństwo otwarte i jego wrogowie $e^{9}$ podejmuje refleksję w nurcie badań nad społeczeństwem otwartym. Twierdzi bowiem, iż właśnie w społeczeństwie otwartym jednostka ma prawo do podejmowania decyzji, w strukturze społeczeństwa uzyskuje możliwość poruszania się w obrębie hierarchii społecznej, ma szansę na awans. W społeczeństwie otwartym istotną rolę odgrywa władza, którą obywatel ma prawo kontrolować, władza ma obowiązek działać dla i na rzecz obywateli, a nie dla zaspokojenia własnych celów czy ambicji. Władza, która służy obywatelowi, może być realizowana w państwach o porządku demokratycznym za pomocą różnego rodzaju instytucji. Dlatego społeczeństwo otwarte wymaga w swoim otoczeniu współdziałania obywateli, zaangażowania obywatelskiego, w przeciwnym razie idea urzeczywistnienia społeczeństwa otwartego będzie wręcz niemożliwa. Sam Karol Popper zdaje sobie również sprawę z faktu, że fenomen, który opisuje, jest zadaniem niezwykle trudnym do wykonania, jednak właśnie w nim upatruje drogę rozwoju zarówno państwa, jak i społeczeństwa.

Należy nadmienić, że idea społeczeństwa obywatelskiego w wieku XX w państwach demokratycznych miała sprzyjające warunki do rozkwitu i rozwoju, demokracja stanowiła i stanowi gwarant realizacji założeń społeczeństwa obywatelskiego; dużo bardziej skomplikowane było usytuowanie idei społeczeństwa obywatelskiego w systemach niedemokratycznych, gdzie była ona zastępowana Popperowskim społeczeństwem otwartym czy ideą społeczeństwa demokratycznego. Dopiero zmiany ustrojowo-systemowe z lat osiemdziesiątych przyczyniły się do nadania koncepcji społeczeństwa obywatelskiego nowego znaczenia.

W dorobku polskiego piśmiennictwa na temat społeczeństwa obywatelskiego odnaleźć można liczne odwołania opisujące i charakteryzujące społeczeństwo obywatelskie. I tak Zbigniew Pełczyński, łącząc podejście republikańskie i liberalne, pisze, że „społeczeństwo obywatelskie jest areną, na której współczesny człowiek znajduje prawo do uzasadniania potrzeb własnych i rozwija swoją jednostkową osobo-

9 K. Popper, Społeczeństwo otwarte i jego wrogowie, t. 1 i 2, Warszawa 2006. 
wość, ucząc się wszakże doceniać działania grupowe i społeczną solidarność oraz dostrzegać, że jego własne dobro zależy od innych. Społeczeństwo obywatelskie uczy go także bycia obywatelem i przygotowuje do działania na arenie politycznej państwa"10.

Piotr Gliński spogląda na społeczeństwo obywatelskie z podwójnej perspektywy, to znaczy twierdzi, że powstanie takiego społeczeństwa aktywnego, demokratycznego, otwartego jest niemożliwe i pozostaje teoretyczną konstrukcją myślową. Z drugiej jednak strony, próbuje odszukać w literaturze wspólne elementy to społeczeństwo tworzące, a należą tu niezależność od władzy, spontaniczność działania, otwartość i budowanie tożsamości, poczucie „sprawstwa obywatelskiego" i realizacja określonych interesów ${ }^{11}$.

Nieco inną interpretację społeczeństwa obywatelskiego odnajdujemy w Strategii Wspierania Rozwoju Społeczeństwa Obywatelskiego na lata 2009-2015, która zawiera twierdzenie definiujące społeczeństwo przez pryzmat rozgraniczeń między przestrzeniami, a mianowicie „społeczeństwo obywatelskie jest przestrzenią działania instytucji, organizacji, grup społecznych i jednostek, rozciągającą się pomiędzy rodziną, państwem i rynkiem, w której ludzie podejmują wolną debatę na temat wartości składających się na wspólne dobro oraz dobrowolnie współdziałają ze sobą na rzecz realizacji wspólnych interesów".

Wspólnym mianownikiem z całą pewnością dla wielu definicji społeczeństwa obywatelskiego sensu stricto i largo jest obecność pojęcia bonum communae, tworzącego oś, wokół której rozbudowywane jest dalsze pole definicyjne. Dobro wspólne ma zachęcać obywateli do aktywnego działania - partycypacja jest zatem kolejnym filarem społeczeństwa obywatelskiego. W nurcie badań nad społeczeństwem obywatelskim wyłania się jeszcze jedna tendencja, a mianowicie do usytuowania koncepcji w sferze między państwem i społeczeństwem, w sferze wolnej od wpływów politycznych, ideologii, jak twierdzi Ralf

10 Z. Pełczyński, Polska droga od komunizmu. Refleksje nad historia i polityka 1956-2006, Warszawa 2007, s. 207.

11 P. Gliński, Style działań organizacji pozarządowych w Polsce. Grupy interesu czy pożytku publicznego?, Warszawa 2006, s. 3-12. 
Dahrendorf ${ }^{12}$. Charles Taylor zauważa natomiast, że „społeczeństwo obywatelskie istnieje wszędzie tam, gdzie istnieją wolne stowarzyszenia poza kuratelą władzy państwowej"13.

Dyskusja wokół koncepcji społeczeństwa obywatelskiego sięga w zakresie od poziomu nienormatywnego, rozumianego jako poziom opisu, poprzez poziom pragmatyczny, wyrażający się w np. formułowaniu strategii politycznych do poziomu normatywnego, zawierającego implikacje moralno-etyczne. Z pewnością definiowanie i ocena społeczeństwa obywatelskiego zanurzona jest w uwarunkowaniach i generacji dokonującej jego podsumowania.

\section{Rola i znaczenie aktywnego uczestnictwa w demokracji - rozważania wokół partycypacji politycznej i wzorców obywatelskości}

Partycypacja, podobnie jak pojęcie społeczeństwa obywatelskiego, z dyskursu akademickiego i naukowego przedostała się do przestrzeni publicznej. W przestrzeni tej jest określeniem wszelkich postaw uczestnictwa i w bardzo szerokim zakresie znaczeniowym stosują je uczestnicy debat publicznych. Tym samym pojęcie partycypacji nie jest wolne od sądów i wartości, bo zawsze należy sformułować pytanie, kto jest uczestnikiem i podmiotem procesów, zdarzeń, jakie są to wydarzenia (istota, charakterystyka, dynamika, przebieg) i w jakich uwarunkowaniach zachodzą.

$\mathrm{Na}$ relatywność wzorca obywatelskiego zwraca uwagę również Zbyszko Melosik w artykule zatytułowanym Wychowanie obywatelskie: nowoczesność, ponowoczesność, formułując tezę, którą przyjmuję jako

12 Por. R. Dahrendorf, Zagrożone społeczeństwo obywatelskie, w: Europa i społeczeństwo obywatelskie. Rozmowy w Castel Gandolfo, red. K. Michalski, Kraków 1994, s. 7.

13 Ch. Taylor, Kiedy mówimy społeczeństwo obywatelskie, w: Europa i społeczeństwo obywatelskie, s. 54. 
obowiązującą na potrzeby niniejszego wywodu, że takie terminy jak „obywatel” czy „obywatelstwo" nie w każdych warunkach historycznych, politycznych, społecznych, kulturowych czy ideologicznych zachowują takie samo znaczenie. Pojęcia te są niejako tworzone i konstruowane w określonych uwarunkowaniach i realiach. „Wychodząc z założeń poststrukturalizmu, można stwierdzić, iż w społeczeństwach trwa dyskursywna walka dotycząca kształtu obywatelstwa (...). Istnieją w tej dziedzinie różne warianty i propozycje - zarówno w teorii, jak i codziennej praktyce politycznej oraz pedagogicznej. W zależności od aktualnej «konstelacji» dyskursów zwycięża ta lub inna opcja. W konsekwencji ten lub inny ideał obywatelstwa i wychowania obywatelskiego staje się «obowiązujący»"14.

Walter Gagel w Einführung in die Didaktik des politischen Unterrichts analizuje znaczenie partycypacji politycznej przez pryzmat pojęć i koncepcji z zakresu kształcenia politycznego ${ }^{15}$. Na samym szczy-

14 Z. Melosik, Wychowanie obywatelskie: nowoczesność, ponowoczesność (próba konfrontacji), „Forum Oświatowe”, 1998 I (18), s. 25-26.

${ }^{15} \mathrm{~W}$ języku niemieckim funkcjonuje pojęcie Politische Bildung, czyli kształcenie polityczne. Bildung, czyli ‘kształcenie' lub ‘edukacja', jest pojęciem wielopłaszczyznowym, interdyscyplinarnym, właściwym dla niemieckiego obszaru językowego, ponieważ każdorazowe tłumaczenie pojęcia będzie skutkowało przesunięciem znaczenia w obrębie tekstu, będzie również zależne od kontekstów, indywidualnych decyzji translatorskich. Nawet jeśli ekwiwalentem pojęcia Bildung stanie się 'edukacja', wówczas z zakresu znaczeniowego zostaje pominięta warstwa emotywności. Bildung nie jest też aktywnością mającą na celu zdobywanie wiedzy, jest swego rodzaju procesem permanentnym „dziejącym się” nieprzerwanie, w którym to procesie zarówno podmiot edukacji jest jej sprawcą. Bildung może być rozumiane zatem nie tylko jako proces, ale również jako rezultat, efekt. Pojęcie Bildung zawiera trzy płaszczyzny. Po pierwsze jest to płaszczyzna kognitywna, będąca płaszczyzną poznania, płaszczyzną logos; po drugie, sfera normatywna, obejmująca wartości, sądy, zapatrywania czy nachylenie ideologiczne, potwierdzająca subiektywny wymiar pojęcia, płaszczyzna ethos; po trzecie, płaszczyzna emotywności, płaszczyzna pathos. To klarowne rozgraniczenie i w pełni świadome zarysowanie granicy, także językowej, pozwala na wyeksponowanie pojęcia Bildung (kształcenia), które obejmuje nie tylko składniki wiedzy potrzebnej do wykonywania zawodu aktora politycznego, ale również wiedzy dotyczącej całego ideowego i aksjologicznego stanu umysłu. Bildung jako kształcenie nie może być więc stosowane jako pojęcie równoznaczne do wykształcenia (Ausbil- 
cie hierarchii umieszcza godność człowieka jako najwyższą wartość, do wartości podstawowych zalicza równość, sprawiedliwość, pluralizm i pokój. Na niższym poziomie wartości politycznych stawia partycypację, demokratyzację, solidarność, dojrzałość, tolerancję, odwagę cywilną oraz poczucie wspólnoty. Na dole wspomnianej hierarchii znajduje się katalog norm i reguł, z których (nie)stosowania i (nie)przestrzegania wynikają konkretne postawy i zachowania ${ }^{16}$.

Partycypacja polityczna jest zarówno procesem „stawania się” dojrzałym obywatelem, ponieważ obywatel poprzez ciągłe uczestnictwo w funkcjonowaniu państwa i społeczeństwa potwierdza swoją rolę oraz wpływ na życie polityczne, społeczne, gospodarcze. Partycypacja jest również wynikiem procesów socjalizacji politycznej, dzięki której obywatel jest przygotowany do pełnienia ról w państwie. Partycypacja będzie zależna od wielu intra czynników takich jak cechy osobowości, usposobienie, wychowanie i środowisko, reprezentowany przez obywatela system wartości czy poglądy polityczne.

$\mathrm{W}$ literaturze przedmiotu $\mathrm{w}$ wielu publikacjach badacze analizują wzorce partycypacji politycznej przez pryzmat opisu przykładnego, idealnego obywatela. Powinien posiadać zestaw określonych cech, które staną się podstawą do kształtowania się postaw czynnego uczestnictwa w życiu politycznym, społecznym czy kulturalnym. Kim zatem jest idealny obywatel? Z pewnością niezwykle ważna jest świadomość faktu, że jest członkiem społeczeństwa, z którego to członkostwa wynikają zarówno prawa, jak i obowiązki. Idealny obywatel będzie również przejawiał aktywność społeczną i polityczną, nie tylko poprzez udział $\mathrm{w}$ wyborach, ale również zaangażowanie w wolontariat, poprzez pracę w organizacjach pozarządowych, poprzez indywidualne działania przyczyniające się do dbałości o bonum communae i zrównoważony rozwój państwa.

Oprócz cech, które charakteryzują aktywnego obywatela, badacze, w szczególności filozofowie, wprowadzają do analizy pojęcie cnoty, bę-

dung), gdyż nie zawsze zdobyte wykształcenie jest miarodajnym odzwierciedleniem stanu wiedzy i umysłu obywatela.

16 W. Gagel, Einführung in die Didaktik des politischen Unterrichts, Opladen 2000, s. 301. 
dącej najstarszym wzorem myślenia etycznego, rozumianej również jako nabyty nawyk do czynienia dobra. Cnota w nurcie myślenia o partycypacji politycznej będzie zatem pożądanym wzorcem zachowań do działania politycznego w państwie demokratycznym ${ }^{17}$.

Ralf Dahrendorf, dokonując podziału na sferę publiczną i prywatną, w której obywatel uczestniczy, wprowadza rozróżnienie cnót na cnoty publiczne związane z relacjami międzyludzkimi oraz cnoty prywatne stojące $\mathrm{w}$ opozycji do wszystkiego co publiczne, związane $\mathrm{z}$ wnętrzem, charakterem, usposobieniem człowieka ${ }^{18}$. Powyższy podział miał na celu przede wszystkim ukazanie warunków historycznych i społecznych do kształtowania się życia politycznego. Autor konstatował również, że dominacja prywatnych cnót może stać się instrumentem działania totalitarnego; tym samym wskazał również na zależność powstającą między formą państwa a wyznawanym i pielęgnowanym katalogiem wartości.

Walter Gagel przywołuje za Christianem von Krockowem przykład kolejnego zestawienia cnót, które dojrzały obywatel w państwie demokratycznym winien posiadać. Do zestawu należą gotowość do kompromisu, umiarkowanie, uznanie istnienia konfliktów, wrażliwość na reguły i zasady, zaufanie i brak zaufania, zaangażowanie i dystans oraz świadomość własnej wartości ${ }^{19}$.

Sebastian Gałecki w swoim artykule zatytułowanym Cnoty obywatela i demokraty $w$ XXI wieku proponuje dokonanie systematyzacji cnót charakteryzujących wzorzec obywatela idealnego. Wyróżnia sześć cnót demokratycznych, do których zalicza, nawiązując do Charlesa Taylora, cnotę autentyczności, rozumianej jako cnota przynależności do określonej wspólnoty, która nie będzie realizowana, jeśli obywatel nie będzie autentyczny, to znaczy mowa tu o cnocie autentyczności rozumianej jako samodzielność myślenia i działania, ale również autentyczność

17 W. Gagel, Einführung, s. 321.

18 R. Dahrendorf, Gesellschaft und Demokratie in Deutschland, München 1965, s. $328-330$.

19 Ch. G. von Krockow, Ethik und Demokratie, Aus Politik und Zeitgeschichte, Beilage zu Das Parlament 49/79 z 08.12.1979, s. 9-17, w: W. Gagel, Einführung, s. $323-324$. 
mieszcząca się między własną kreacją a wyobrażeniami, które ma o danym obywatelu grupa społeczna, organizacja, środowisko, społeczeństwo $^{20}$. W dalszej kolejności wymienia cnotę poszukiwania i umiłowania wolności, w tym również wolności wewnętrznej, cnotę tolerancji rozumianej jako cierpliwość i poszanowanie, a nie w nurcie postmodernistycznym jako powszechną akceptację wszystkiego, cnotę odpowiedzialności czyli gotowości do ponoszenia odpowiedzialności za swoje czyny, w tym również odpowiedzialności za innych. Dalej mowa o cnocie patriotyzmu, czyli postawach, które charakteryzują się lojalnością, gotowością poświęcenia się na rzecz i dla dobra wspólnoty oraz zachowania głosu krytycznego w odniesieniu do zastanego porządku. Dojrzały obywatel będzie również cechował się cnotą zdrowego rozsądku, czyli będzie posiadał cechy takie jak umiejętność prowadzenia dialogu, debaty publicznej, taki obywatel będzie gotów wysłuchać i przyjąć odmienne stanowiska.

W polskojęzycznej literaturze przedmiotu w tle rozważań o cnotach obywatelskich pozostaje artykuł Marii Ossowskiej zatytułowany Wzór obywatela w ustroju demokratycznym, w którym zestawia listę trzynastu cech, do których zalicza: aspiracje perfekcjonistyczne, otwartość umysłu, dyscyplinę wewnętrzną, tolerancję, aktywność, odwagę cywilną, uczciwość intelektualną, krytycyzm, odpowiedzialność za słowo, uspołecznienie, rycerskość, wrażliwość estetyczną i poczucie humoru. Wprawdzie esej Marii Ossowskiej powstał w czasach socjalizmu, a autorka nie określa w sposób precyzyjny, jakiego demokratę charakteryzuje: czy demokratę - przedstawiciela krajów demokracji ludowej, czy demokratę obywatela państwa socjalistycznego czy też demokratę „powojennego”, jednak należy zaznaczyć, iż Maria Ossowska w swej charakterystyce nadaje szczególne znaczenia wzorcom kultury, które bądź zadane, bądź wypracowywane w społeczeństwie, stają się nośnikiem postaw i zachowań, a tym samym kluczem do zrozumienia określonych ideałów i wzorców osobowych. Mimo że niniejszy tekst nie wyczerpuje w pełni opisu, a wzorzec obywatela-demokraty ewoluuje, pozostając w ścisłym związku z ustrojem polityczno-społeczno-gospodarczym, to należy zauważyć,

${ }^{20}$ Ch. Taylor, Etyka autentyczności, Kraków 1996. 
że Maria Ossowska jako jedna z pierwszych zabiera ważny głos w dyskusji publicznej na temat postaw obywatelskich ${ }^{21}$.

Liczne katalogi cnót obywatelskich poprzez wyeksponowanie określonych cech zaznaczają niejako obszary aktywności obywatelskiej i ukazują, gdzie można nakreślić granicę zaangażowania i uczestnictwa, przy czym należy nadmienić, że wyznaczenie granic partycypacji nie stanowi o istnieniu systemu zero-jeden, w którym jako zero rozumie się całkowity brak zaangażowania obywatelskiego, natomiast jeden - oznaczałoby pełne zaangażowanie. Wyznaczenie tych granic należy traktować raczej jako próbę wskazania obszarów aktywności. Poza rozważaniami w tym miejscu pozostaje nasilenie postaw partycypacji (zaangażowanie duże, średnie, małe) oraz ewaluacja postaw.

W kulturze ponowoczesnej występują również mieszanki tych cech, tożsamość nie jest pojęciem jednowymiarowym i homogenicznym, wskutek różnych czynników społecznych (np. migracje) nabiera zupełnie innego - nowego znaczenia. I tak Habermasowska wizja kosmopolityczna wzoru obywatela nawołująca do stworzenia obywateli świata, obywateli będących jednocześnie uczestnikami dwóch przestrzeni: ogólnoświatowej i narodowej, traci swą ważność na rzecz rozwiązań ponadpaństwowych, supranarodowych. Współczesna wizja obywatela wskazuje jednak w dużej mierze na odejście od koncepcji kosmopolitycznej; obywatel nie jest przypisany ani do konkretnego narodu, ani do korzeni, nie jest też wizjonerem i kreatorem przeszłości. Obywatel jest więc nie tylko obywatelem państwa, członkiem społeczeństwa, jest również wpisany swoją istotą w rozliczne interakcje społeczne na płaszczyźnie lokalnej, regionalnej i subregionalnej. Zadaniem dojrzałego obywatela będzie podejmowanie ciągłych wysiłków zmierzających do pogodzenia partykularnych interesów wyżej wspomnianych przestrzeni.

Z wielości cech określających aktywnych, uczestniczących obywateli krystalizują się poszczególne typy osobowości, które Helmut Klages, wykorzystując teorię ról, klasyfikuje w następującym porządku: idealista, konwencjonalista, materialista i aktywny realista. Każdy z typów określa, jak obywatel wypełnia swą rolę, jakie jest jego nastawienie do

${ }^{21}$ M. Ossowska, Wzór demokraty. Cnoty i wartości, Lublin 1992. 
pełnienia ról politycznych i społecznych, wyobrażenia o tych rolach, przesłanki i bariery ich pełnienia. Idealista zorientowany jest na własny rozwój i samodoskonalenie, przy czym ma wyraźnie obniżony próg partycypacji, niechętnie uczestniczy w projektach i akcjach o charakterze polityczno-społecznym. Spełnia jedynie podstawowe obowiązki obywatela takie jak posłuszeństwo czy poszanowanie prawa. Na drugim biegunie od idealisty funkcjonuje model obywatela-konwencjonalisty, który z wielkim zaangażowaniem wypełnia role obywatela, ma wiedzę na temat funkcjonowania państwa i panujących reguł, jednak nie jest nastawiony na samokształcenie i zaangażowanie. To raczej typ, który funkcjonuje biernie, podatny na wpływy. Materialista reprezentuje konsumpcyjny, hedonistyczny tryb życia, nie jest zainteresowany polityką i problematyką w stopniu znaczącym, chociaż wiele oczekuje od polityki w odniesieniu do statusu materialnego. Aktywni realiści to obywatele świadomi swoich praw, gotowi do aktywnego uczestnictwa w życiu politycznym i społecznym, zainteresowani własnym rozwojem i realizacją własnych celów i inspiracji. Helmut Klages właśnie w tym typie upatruje model idealnego obywatela, gdyż z jednej strony cechuje go wewnętrzna mobilizacja, z drugiej natomiast świadomość uczestniczenia w warunkach demokracji. Nie chodzi tu o to, by obywatel był aktywny we wszystkich możliwych sferach i przedsięwzięciach, ale o to, by włączał się w projekty „motywowane”, czyli te, w których jego działanie jest nieodzowne i ważne. Należy również pamiętać, że w powyższym uogólnieniu Helmut Klages przede wszystkim nałożył na siebie dwie zmienne: potrzebę własnego rozwoju i zaangażowanie w życie polityczne i społeczne. Oznacza to, że w opisywanych postawach przebija się motyw maksymalizacji korzyści własnej, który może nieco zaburzać obraz pełnego opisu typu obywatela, a jednocześnie go uzupełniać poprzez odwołanie do realizacji prywatnych, partykularnych interesów ${ }^{22}$.

Joachim Detjen uzupełnia opis typów obywateli poprzez dokładniejszą analizę ról, jakie pełnią w społeczeństwie. Wyróżnia zatem model

22 H. Klages, Der „schwierige” Bürger - Bedrohung oder Zukunftspersonal, w: Demokratie am Wendepunkt. Die demokratische Frage als Projekt des 21. Jahrhunderts, red. W. Weidenfeld Berlin 1996, s. 244-250 oraz A. Wiktorska-Święcicka, Od obywatela dobrego do dojrzałego, Wrocław 2011, s. 376-377. 
obywatela, który nie jest zainteresowany polityką, a który w typologii Helmuta Klagesa mieści się między konwencjonalistą z zamiłowaniem do uporządkowania a hedonistycznym materialistą. To obywatel odległy od polityki, z niewielką wiedzą obywatelską, nieuczestniczący w życiu społecznym i politycznym, zabiegający o jak najmniejszy kontakt ze światem polityki i z tym, co polityczne. W dalszej kolejności badacz wyróżnia typ obywatela zdolnego do refleksji. Do tej grupy należeliby wszyscy przedstawiciele typologii Helmuta Klagesa poza materialistą. Jest to obywatel, którego charakteryzuje bardzo słaba postawa uczestnicząca, niechętnie chodzi na wybory, niechętnie uczestniczy w akcjach i projektach obywatelskich, jednak wykazuje niewielkie zainteresowanie tematyką polityczną, chce mieć wystarczający wolumen wiedzy politologicznej, aby móc uczestniczyć w dyskusjach i prezentować swoje stanowisko. Obywatel zdolny do interwencji (działania) to kolejny typ należący do Detjenowskiego zestawienia, charakteryzujący się wysoką gotowością do działania w konkretnych sytuacjach, w które się włącza na zasadzie reakcji i interwencji, natomiast nie jest stale zainteresowany polityką, choć ma zaufanie do władzy i instytucji publicznych, pozwalające mu wierzyć i działać dla dobra wspólnego. To typ, który mieści się w postawach aktywnego realisty i niekonformistycznego idealisty. Docenić należy jego umiejętność włączenia się w działanie wspólnotowe, jednak działanie to nie może być wycinkowe i fragmentaryczne, a powinno towarzyszyć całemu procesowi sprawczemu, od koncepcji do rezultatu. Ostatni model to obywatel aktywny. Życie polityczne, aktywne w nim uczestnictwo mają dla niego istotne znaczenie; obywatele aktywni to najczęściej członkowie partii politycznych, klubów, stowarzyszeń, związków. Są świadomi, jak ważną rolę odgrywa każdy obywatel w społeczeństwie, nie przeceniają jej, ale w sposób pełny biorą udział w funkcjonowaniu państwa i życiu społeczeństwa ${ }^{23}$.

23 http://www.bpb.de/apuz/25554/die-demokratiekompetenz-der-buerger?p =all (dostęp: 11.11.2016). Por. także P. Massing, Bildungspolitik in der Bundesrepublik Deutschland, Entwicklung - Kontroversen - Perspektiven, Schwalbach/Ts. 2002, s. 113-115. Autor wyróżnia w sposób bardziej szczegółowy trzy typy obywatela: obywatela myślącego, obywatela interweniującego i obywatela aktywnego. Do Massinga nawiązuje później Ackermann z podobną koncepcją wzorców 
Pamiętajmy jednak, że rozbudowane i rozliczne typologie i klasyfikacje są podstawą debat i sporów w obszarze wzorców obywatela i charakteryzujących go postaw. Autorzy nadają cnotom szczególne znaczenie i czynią je warunkiem koniecznym do zaistnienia demokracji, tak jak u Roberta Dahla, uważają je, wzorem Jürgena Habermasa, za warunek konieczny dobrego życia. Powstaje zatem pytanie: kto jest adresatem owych dyskusji i sporów, nie tylko politycznych, ale filozoficznych i aksjologicznych? Czy jest to apel do obywateli wzywający ich do aktywności publicznej i politycznej? Czy debaty te kierowane są również do instytucji, których celem jest kształtowanie przestrzeni publicznej i realizacji wpisanej w niej działalności, w tym również działalności edukacyjnej? Czy też może szczególnie uważnymi słuchaczami winni być nauczyciele, pedagodzy, dziennikarze, rodzice, a zatem wszyscy ci, którzy odpowiedzialni są za przekazywanie wiadomości i umiejętności, wartości i postaw. Czy też dyskusja akademicka ma za zadanie wypełnianie przestrzeni analizą i interpretacją, stanowiąc potem rezerwuar idei i wartości dla wyżej wymienionych grup?

Do badań nad partycypacją polityczną wiele wnoszą ustalenia Roberta Putnama, który analizując tradycje obywatelskie we współczesnych Włoszech, ukazuje zależności między uniwersalnymi właściwościami i cechami obywatela. Autor w tym szeroko zakrojonym projekcie empirycznym dowodzi, że zaangażowanie obywatelskie jest tym większe, im bardziej obywatele sobie ufają, czyli bez kapitału wzajemnego zaufania nie można tworzyć kapitału społecznego czy politycznego. Oznacza to, że obywatel, który nie ma zaufania do siebie samego, nigdy nie będzie ufał innym obywatelom ani władzy. Ten mechanizm działa na zasadzie sprzężenia zwrotnego, to znaczy obywatel opierający swoje działanie na zaufaniu społecznym, zaufaniu do władzy publicznej, będzie aktywnym i dojrzałym obywatelem. Robert Putnam wskazuje również na kolejne zależności: partycypacja polityczna jest najwyższa tam, gdzie najniższy jest współczynnik korupcji, a ożywione i aktywne ży-

obywatelskich. P. Ackermann, Die Bürgerrolle in der Demokratie als Bezugsrahmen für die politische Bildung, w: Die Rückkehr des Bürgers in die politische Bildung, red. G. Breit, P. Massing, Wochenschau Verlag, Schwalbach/Ts. 2002. 
cie społeczne, jak np. udział w akcjach i projektach społecznych, członkostwo w stowarzyszeniach, ugrupowaniach czy związkach, wpływa bezpośrednio na stopień zadowolenia obywatela z demokracji ${ }^{24}$. Bardzo ważną rolę badacz przypisuje różnego rodzaju instytucjom, które wypełnione działaniem obywatelskim, stają się efektywne, pełnią funkcję forum dyskusyjnego, obywatele mogą poprzez te instytucje realizować swoje interesy - to zadaniem państwa jest tworzenie dogodnych warunków do powstawania i działalności instytucji.

Konkludując, należy stwierdzić, że literatura przedmiotu z zakresu kształcenia politycznego, społeczeństwa obywatelskiego, wzorców i postaw obywatelskich wykazuje podział ze względu na charakter opisu, to znaczy jedną z grup będą tworzyć analityczne opracowania podejmujące dyskurs teoretyczny (Joachim Detjen, Peter Massing, Aldona Wiktorska-Święcicka, Wolfgang Sandner), do drugiej zaś grupy zaliczyć można publikacje i wydawnictwa o charakterze apelatywnym, nawołujące do zmian, formułujące rekomendacje, wchodzące w polemikę na temat ról (Robert Putnam, Peter Lange).

\section{Wnioski}

Giovanni Sartori twierdził, że demokracja może żyć tylko wtedy, kiedy jest rozumiana przez obywateli, tak też istotne jest zdobywanie kolejnych kompetencji, ale i nabycie świadomości oraz wiedzy, że każdy obywatel może mieć wpływ na otaczającą go rzeczywistość. Aktywna działalność obywatela znajduje się w centrum rozważań wokół społeczeństwa obywatelskiego, chociaż samo pojęcie społeczeństwa obywatelskiego jest niezwykle pojemne i nastręcza badaczom nie lada trudności w konstruowaniu definicji i modeli teoretycznych. Społeczeństwo obywatelskie daje podłoże do podejmowania aktywności, natomiast aktywność jest efektem działania w warunkach demokratycznych, które z kolei umożliwiają kształtowanie się społeczeństwa obywatelskiego.

${ }^{24}$ R. Putnam, Demokracja $w$ działaniu. Tradycje obywatelskie we współczesnych Włoszech, Kraków 1995. 
Immanentną cechą społeczeństwa obywatelskiego jest partycypacja polityczna. Max Kasse wyprowadza twierdzenie, że obecnie mamy do czynienia z „rewolucją partycypacyjną"25, co oznacza, że na przestrzeni ostatnich dziesięcioleci wzrasta liczba obywateli aktywnych, zainteresowanych polityką, uczestniczących w konwencjonalnych (akcje, wiece, członkostwo w stowarzyszeniach, partiach politycznych etc.) oraz niekonwencjonalnych (strajk, nielegalne formy protestu, różne formy nieposłuszeństwa obywatelskiego) formach partycypacji.

W partycypacji politycznej można zaobserwować również tendencje i kierunki zmian, przy czym zastrzega się, że partycypację polityczną na potrzeby niniejszej analizy należy rozumieć jako pewien bezgraniczny fenomen, a nie jako zestaw zachowań wybranej populacji w konkretnym miejscu i czasie.

Po pierwsze, partycypacja polityczna stała się działaniem określonym, zorientowanym na sytuację czy zdarzenie, konkretnym działaniem $\mathrm{w}$ tle $\mathrm{z}$ konkretnym kontekstem i uwarunkowaniami społecznymi, politycznymi, gospodarczymi, kulturowymi, normatywnymi, ideologicznymi czy religijnymi.

Po drugie, badacze nadal poszukują jednolitego języka opisu postaw i wzorców, który ma umożliwić dokonywanie porównań i ewaluacji w zakresie badań nad partycypacją polityczną.

Po trzecie, poszerzyło się spektrum form partycypacji politycznej od czynnego uczestnictwa poprzez wyraz oporu i niezadowolenia społecznego, gdyż nieposłuszeństwo obywatelskie jest przecież przejawem aktywności obywatelskiej.

Po czwarte, partycypacja polityczna nie może być rozumiana tylko i wyłącznie jako przejaw określonych postaw, a właściwie ich rezultat (chcę mieć wpływ na realia - biorę udział w głosowaniu), ale jest również swego rodzaju procesem wpisanym w zjawisko kształcenia - Bildung.

Po piąte, partycypacja polityczna przyczyna się do stabilności i legitymizacji systemu demokratycznego, co pozwala oczekiwać, że jakość i efektywność działalności instytucji politycznych będzie wyższa.

25 G. Breit, P. Massing (red.), Die Rückkehr, s. 65. 
Państwo nie może istnieć bez obywateli, a ramę do funkcjonowania obywateli w państwie stwarza demokracja, która nakłada na nich nie tylko obowiązki, ale i prawa do uczestnictwa w życiu publicznym, do uczestnictwa w rządzeniu, do artykułowania swoich postaw i stanowisk. W demokracji obywatele podlegają tym normom, które z demokracji wynikają per se, oraz normom i wartościom, do przestrzegania których sami się zobowiążą. Analizując zatem zależność między świadomym obywatelem, zaopatrzonym w wiedzę i kompetencje, a środowiskiem i państwem, w którym żyje, warto zwrócić uwagę na fakt, że w powyższej relacji obowiązuje zasada ścisłej wzajemności, to znaczy że demokracja tworzy obywatela, stwarzając uwarunkowania do działania, ale i obywatel tworzy i konstruuje demokrację, która nie może istnieć tylko i wyłącznie jako idea czy wyobrażenie. Oznacza to, że ta zależność między świadomym obywatelem a demokracją jest swego rodzaju transakcją wymienną, z której korzystają obie strony, ale i obie strony są za jej powodzenie współodpowiedzialne.

Debata na temat postaw obywatelskich w zmieniających się uwarunkowaniach historycznych, społecznych, politycznych, gospodarczych, kulturowych, religijnych czy ideologicznych wpisuje się w nurt badań interdyscyplinarnych prowadzonych nad obywatelstwem. Procesy globalizacji, nasilające się w ostatnim czasie fale migracyjne o charakterze uchodźczym i ekonomicznym, wzrost znaczenia państw narodowych, zmiany paradygmatów integracyjnych i wzorców asymilacji skutkują koniecznością redefinicji pojęć z zakresu obywatelstwa, partycypacji czy kultury politycznej. Zmieniają się również wzorce obywatelskości kształtujące się w otoczeniu społeczeństwa obywatelskiego, a zmiany te dotyczą nie tylko państw przyjmujących, ale wszystkich aktorów środowiska międzynarodowego. 


\section{Bibliografia}

Breit, Georg, Peter Massing. Die Rückkehr des Bürgers in die politische Bildung.

Schwalbach/Ts.: Wochenschau Verlag, 2002.

Brix, Emil (Hg.). Civil Society in Österreich. Wien: Passagen-Verlag, 1998.

Cyceron. O państwie. O prawach, przeł. Iwona Żółtowska. Kęty: Wydawnictwo Antyk, 1999.

Dahrendorf, Ralf. Gesellschaft und Demokratie in Deutschland. München: R. Piper \& Co., 1965.

Gagel, Walter. Einführung in die Didaktik des politischen Unterrichts. Opladen: VS Verlag für Sozialwissenschaften, 2000.

Gliński, Piotr. Style działań organizacji pozarządowych w Polsce. Grupy interesu czy pożytku publicznego?, Warszawa: IFiS PAN, 2006.

Habermas, Jürgen. Rzecz o kondycji i ustroju Europy, przeł. Andrzej Kaniewski. Łódź: Wydawnictwo Uniwersytetu Łodzkiego, 2014.

http://www.mpips.gov.pl/userfiles/File/pozytek/SWRSO\%202009-2015.pdf (dostęp: 31.05.2017).

https://wolnelektury.pl/media/book/pdf/o-duchu-praw.pdf (dostęp: 01.06.2017).

Kant, Immanuel. Metafizyczne podstawy nauki prawa. Kęty: Wydawnictwo Antyk, 2006.

Massing, Peter. Bildungspolitik in der Bundesrepublik Deutschland, Entwicklung - Kontroversen - Perspektiven. Schwalbach/Ts: Wochenschau Verlag, 2002.

Melosik, Zbyszko. „Wychowanie obywatelskie: nowoczesność, ponowoczesność (próba konfrontacji". Forum Oświatowe I (18) (2011): 25-46.

Michalski, Krzysztof (red.). Europa i społeczeństwo obywatelskie. Rozmowy $w$ Castel Gandolfo. Kraków: Społeczny Instytut Znak, 1994.

Ossowska, Maria. Wzór demokraty. Cnoty i wartości. Lublin: Daimonion, 1992.

Pełczyński, Zbigniew. Polska droga od komunizmu. Refleksje nad historia i polityka 1956-2006. Warszawa: Wydawnictwo Naukowe Scholar, 2007.

Pietrzyk-Reeves, Dorota. Idea społeczeństwa obywatelskiego: Współczesna debata i jej źródła. Toruń: Wydawnictwo Naukowe UMK, 2012.

Poboży, Błażej. „Idea społeczeństwa obywatelskiego”, Społeczeństwo i Polityka 1 (2005): 13-20. 
Popper, Karl. Społeczeństwo otwarte i jego wrogowie, tom 1 i 2. Warszawa: Wydawnictwo Naukowe PWN, 2006.

Putnam, Robert. Demokracja $w$ działaniu. Tradycje obywatelskie we wspótczesnych Włoszech. Kraków: Społeczny Instytut Wydawniczy ZNAK, 1995.

Reese-Schäfer, Walter. Politische Theorie heute. Neuere Tendenzen und Entwicklungen. München: Oldenbourg Verlag, 2000.

Sowa, Kazimierz Zbigniew. Szkice o sferze publicznej i polskim społeczeństwie obywatelskim. Kraków: Wydawnictwo Uniwersytetu Jagiellońskiego, 2012.

Taylor, Charles. Etyka autentyczności. Kraków: Społeczny Instytut Wydawniczy Znak, 1996.

Weidenfeld, Werner (Hrsg.). Demokratie am Wendepunkt. Die demokratische Frage als Projekt des 21. Jahrhunderts. Berlin: Siedler Verlag, 1996.

Wiktorska-Święcicka, Aldona. Od obywatela dobrego do dojrzałego. Wrocław: Oficyna Wydawnicza ATUT, 2011. 